\title{
Spatio-Temporal Change of Land Surface Temperature at Tiris Geothermal Potential Area, East Java, Indonesia.
}

\section{$\$$ sciendo}

Andre Prayogo ${ }^{1,3}$, Sukir Maryanto ${ }^{2,3}$, Ahmad Nadhir ${ }^{2,3}$

${ }_{1}^{1}$ Postgraduate Program of Physics, Faculty of Mathematics and Natural Science, Brawijaya University, Malang, Indonesia.

${ }^{2}$ Department of Physics, Faculty of Mathematics and Natural Science, Brawijaya University, Malang, Indonesia.

${ }^{3}$ Brawijaya Volcanology and Geothermal Research Center, Faculty of Mathematics and Natural Science, Brawijaya University, Malang, Indonesia

*Corresponding Author Email : sukir@ub.ac.id

\section{DOI: 10.2478/pjg-2019-0002}

\begin{abstract}
One of the areas that have geothermal potential in Indonesia is Tiris because there are found some manifestation in the form of hot springs. Several studies are needed to determine its geothermal potential before exploitation is carried out. Some previous studies have been carried out in the area, one of which uses Landsat 7 remote sensing data. There are other studies that state that knowledge of geology is needed to implement remote sensing in determining geothermal areas. This study uses 3-years data from Landsat 8 and geological information from the regional geological map of the study area. The result show changes in the value of Normalized Difference Vegetation Index (NDVI) and Land Surface Temperature (LST) from year to year, where each year the NDVI value decrease which is interpreted as reduced vegetation in the study area. From the distribution of LST values in the study area, it was found that there were hot spots that had higher temperatures than the surrounding area. When geological information and LST distribution map overlaid with regional geological maps, it is known that the hot spots inside the research area are possible to be a geothermal reservoir.
\end{abstract}

\section{KEYWORD}

Remote Sensing, Time Lapse, Temperature Anomaly

\section{INTRODUCTION}

The location of The Tiris Village is in Probolinggo District, East Java, Indonesia. In this area found manifestation (hot springs) which is sign of the existence of geothermal potential, shown in Figure 1. Based on Indonesia Minister of Energy and Mineral Resources[1], Tiris has geothermal potential about 74 MWe allegedly around the Lamongan Volcano. Before this geothermal potential was exploited, some geophysical studies are needed such as those carried out in potential geothermal areas, such as Songgoriti-Kasinan, Cangar, Blawan, and Wurung Creater [2-9]. Preliminary study using gravity data has been done in 2018 by Maryanto et al[10], with result that Tiris Geothermal Area is volcano hosted geothermal. Andesitic-lava rocks from The Argopuro Volcano are suspected as the geothermal heat source, and breccia-lava from The Lamongan Volcano that have large porosity suspected as the geothermal reservoir. According to Suharsono and Surwati, 1992 in Geological Map of The Probolinggo Quadrangle, Java[11], the site of the appearance of geothermal manifestations is right on the fault at Tiris Potensial Geothermal Area, northeast of Lamongan Volcano. Another method has been done by Faridah and Krisbiantoro in 2014[12] using remote sensing method by Landsat 7 imaging instrument data from years 2010 - 2013. This method produces an estimate of the surface temperature of the land in Lamongan Volcano area. The alleged presence of geothermal energy in the Lamongan Volcano area due to heat distribution with temperature ranging from $37^{\circ} \mathrm{C}-6^{\circ}{ }^{\circ} \mathrm{C}$. Study about remote sensing using Landsat 8 for detection geothermal anomalies in Tulu Moye geothermal prospect at year 2019 by Darge et al[13] says that detecting geothermal area is more efficient by combining remote sensing and geology knowledge.
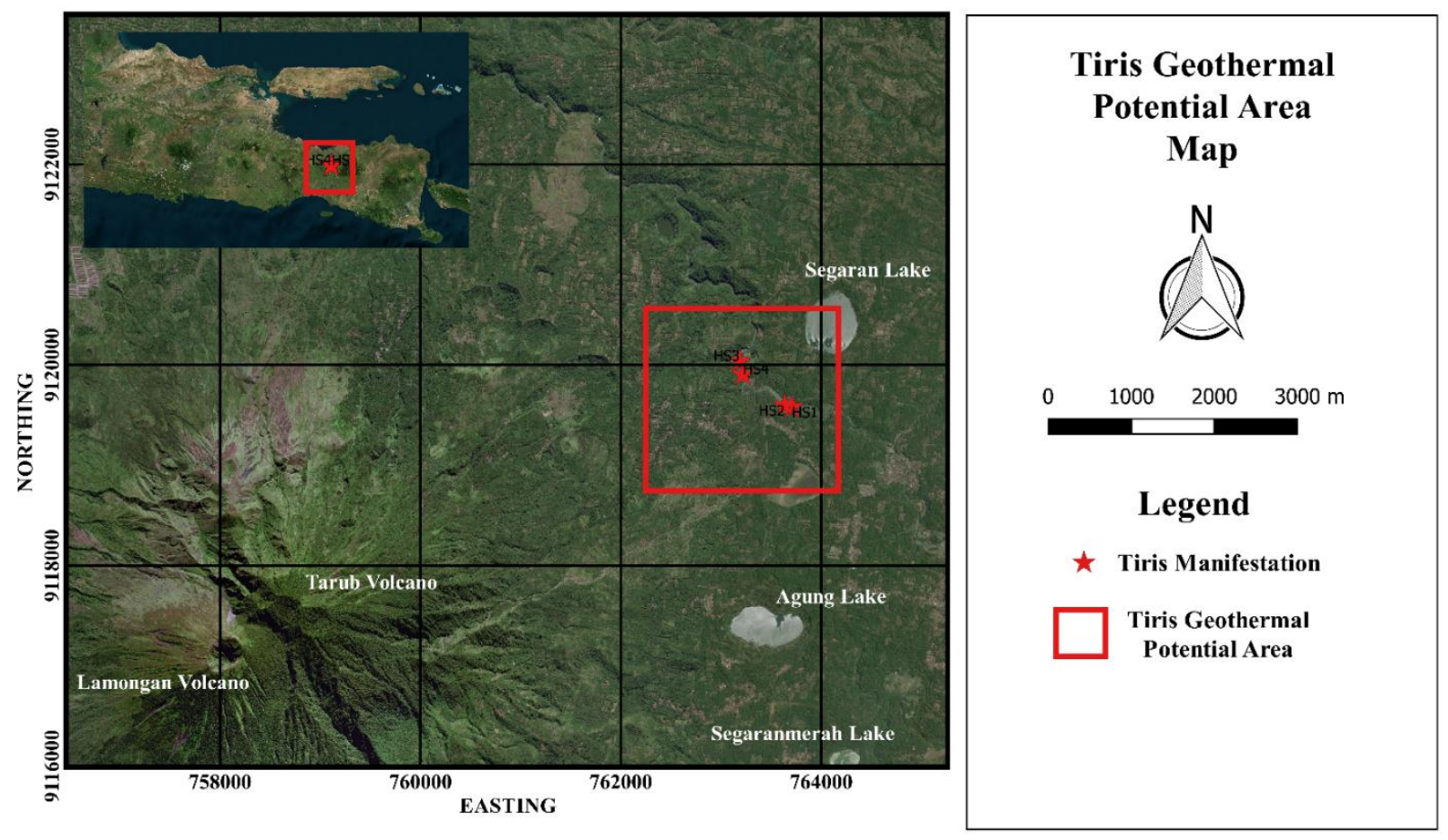

Figure 1: Tiris Geothermal Potential Area with the location of hot springs. 
Remote sensing is the method of getting some information about object, region, or phenomenon from data analysis from a tool without direct contact with the object examined[14]. Artificial satellites that can be used for remote sensing are Landsat 7 and Landsat 8 which were launched in 2013 and operate until now. Landsat 7 has 1 sensor with the recording of six bands while Landsat 8 has 2 sensors, OLI (Operational Land Imager) and TIRS (Thermal InfraRed Sensors) with eleven bands recording[15-18]. The difference in band ranges between Landsat 7 and Landsat 8 is shown in Table 1.

Table 1: Difference in band ranges between Landsat 7 and Landsat 8.

\begin{tabular}{|c|c|c|c|}
\hline Satellite & Band Name & Range $(\mu \mathrm{m})$ & Resolution (m) \\
\hline Landsat 7 ETM+ & $\begin{array}{c}\text { Band } 1 \text { Blue } \\
\text { Band } 2 \text { Green } \\
\text { Band } 3 \text { Red } \\
\text { Band } 4 \text { NIR } \\
\text { Band } 5 \text { SWIR-1 } \\
\text { Band } 6 \text { TIR } \\
\text { Band } 7 \text { SWIR-2 } \\
\text { Band } 8 \text { Pan } \\
\text { Band } 1 \text { Aerosol }\end{array}$ & $\begin{array}{l}0.441-0.514 \\
0.519-0.601 \\
0.631-0.692 \\
0.772-0.898 \\
1.547-1.749 \\
10.31-12.36 \\
2.064-2.345 \\
0.515-0.896 \\
0.435-0.451\end{array}$ & $\begin{array}{l}30 \\
30 \\
30 \\
30 \\
30 \\
60 \\
30 \\
15 \\
30\end{array}$ \\
\hline \multirow{10}{*}{ Landsat $8 \mathrm{OLI}$ and TIRS } & Band 2 Blue & $0.452-0.512$ & 30 \\
\hline & Band 3 Green & $0.533-0.590$ & 30 \\
\hline & Band 4 Red & $0.636-0.673$ & 30 \\
\hline & Band 5 NIR & $0.851-0.879$ & 30 \\
\hline & Band 6 SWIR-1 & $1.566-1.615$ & 30 \\
\hline & Band 7 SWIR-2 & $2.107-2.294$ & 30 \\
\hline & Band 8 Pan & $0.503-0.676$ & 15 \\
\hline & Band 9 Cirrus & $1.363-1.384$ & 30 \\
\hline & Band 10 TIR-1 & $10.60-11.19$ & 100 \\
\hline & Band 11 TIR-2 & $11.50-12.51$ & 100 \\
\hline
\end{tabular}

This study carried out in addition to updating the data, as well as to determine the effect of the location of the manifestation and regional geology on the approximate land surface temperature (LST), based on Landsat 8 spatio-temporal change thermal infrared image.

\section{MATERIAL AND METHODS}

\subsection{Data Used}

The data used in this study is secondary data obtained freely on the USGS online site. This data is the result of recording by Landsat 8 satellite in the form of 11 band recordings per data packet. Data is downloaded at path 118 row 65 for 3 years $(2016-2018)$ with land cloud cover parameter around 10 or less to minimize noise. The download data used are in June $4^{\text {th }} 2016$, September $9^{\text {th }} 2017$, and October $22^{\text {th }} 2018$.

\subsection{Processing}

Data processing in this study is using Qgis software version 2.18.27 Las Palmas. Calculation of NDVI value that express how dense vegetation in an area and can empirically determine surface emissivity. NDVI value ranged by -1 to 1 , where negative value shown more tenuous vegetation. Using equation 1 , we can calculate NDVI value[19].

$$
N D V I=\frac{\rho_{\text {nir }}-\rho_{\text {red }}}{\rho_{\text {nir }}+\rho_{\text {red }}}
$$

Where $\rho_{\text {nir }}$ and $\rho_{\text {red }}$ are ToA (Top of Atmospheric) that can obtained using equation 2 [20].

With,

$$
\rho_{\lambda}=\frac{M_{\rho} \times Q_{c a l}+A_{\rho}}{\sin \theta}
$$

$\rho_{\lambda} \quad=$ ToA reflectance with sun elevation correction

$M_{\rho} \quad=$ Band reflectance multiple factor

$Q_{\text {cal }}=$ DN value

$A_{\rho} \quad=$ Band reflectance add factor

$\theta \quad=$ Sun elevation

Calculation of vegetation fraction $\left(P_{v}\right)$ is represent vegetated land cover in an area that can be calculate by equation $3[20]$

$$
P_{v}=\left(\frac{N D V I-N D V I_{s}}{N D V I_{v}-N D V I_{s}}\right)^{2}
$$

Where $N D V I_{s}$ is value for minimum NDVI (tenuous or with no vegetation) and $N D V I_{v}$ is value for maximum NDVI (dense vegetation).

According to Sobrino et. al, 2004[20], soil emissivity $\left(\varepsilon_{s}\right)$ can calculate with some conditions,

1) $\mathrm{NDVI}<N D V I_{S}(0.2)$, value of soil emissivity is 0.97 .

2) NDVI $>N D V I_{v}(0.65)$, value of soil emissivity is 0.99 .

3) $0.2 \leq \mathrm{NDVI} \geq 0.65$, value of soil emissivity can calculate by using equation 4 .

With,

$$
\varepsilon_{s}=m P_{v}+n
$$

$$
\begin{gathered}
m=\varepsilon_{v}-\varepsilon_{s}-\left(1-\varepsilon_{s}\right) F \varepsilon_{v} \\
n=\varepsilon_{s}+\left(1-\varepsilon_{s}\right) F \varepsilon_{v}
\end{gathered}
$$

$F=$ form factor $(0.55)$

Land surface temperature (LST) can be calculated, firstly by process band 11 image from Landsat 8 OLI to radiance spectral value using equation 7[15].

Where,

$$
L_{\lambda}=M_{L} \times Q_{c a l}+A_{L}
$$

$L_{\lambda} \quad=$ Radiance spectral $\left(\mathrm{W} \cdot \mathrm{m}^{-2} \cdot \mathrm{sr}^{-1} \cdot \mu \mathrm{m}^{-1}\right)$

$M_{L} \quad$ = Band radiance multiple factor

$Q_{\text {cal }}=$ DN value

$A_{L} \quad=$ Band radiance add factor

Using equation 8[17], the result of radiance spectral calculation changed into temperature brightness $\left(T_{\text {sensor }}\right)$.

$$
T_{\text {sensor }}=\frac{K_{2}}{\ln \left(\frac{K_{1}}{L_{\lambda}}+1\right)}-273.15
$$

Where,

$K_{1} \quad=$ Band 11 thermal conversion constant 1.

$K_{2} \quad=$ Band 11 thermal conversion constant 2 .

Then calculate land surface temperature using equation 9[17]. 


$$
T_{s}=\frac{T_{\text {sensor }}}{1+\left(\lambda^{T} \frac{T_{\text {sensor }}}{h c / j}\right) \ln \varepsilon_{S}}
$$

Where,

$T_{S} \quad=$ Land surface temperature $(\stackrel{\circ}{\circ} \mathrm{C})$

$T_{\text {sensor }}=$ Temperature brightness

$\lambda=$ band 11 radiance emissivity wavelength $(11.5 \mu \mathrm{m})$

$h \quad=$ Planck constant $\left(6.63 \times 10^{-34} \mathrm{Js}\right)$

c $\quad=$ speed of light $\left(2.99 \times 10^{8}\right.$ m.s.

$\varepsilon_{s} \quad=$ soil emissivity

\section{RESULT AND DISCUSSION}

The result of processing Landsat 8 images that get the distribution of NDVI value can be seen in figure $2-4$, and distribution of land surface temperature can be seen in figure 5 - 7. According to Qin et. al, 2011[19], value of NDVI can be grouped into 3, NDVI > 0.65 shows land covered with vegetation, $0.2<$ $\mathrm{NDVI} \leq 0.65$ show mixed land, and NDVI $\geq 0.2$ is deforested or covered with water. In figure 2, shows that inside Tiris Geothermal Potential Area at year 2016, NDVI values vary from 0.2 to 0.8 . Distribution of high NDVI values is more evenly distributed, this indicates that the area has dense vegetation cover. Figure 3 shows almost same pattern but distributed of high NDVI value have decreased to 0.7. Figure 4 shows a significant decrease in the value of NDVI at year 2018, this means that inside of Tiris Geothermal Potential Area undergoes a change which originally had dense vegetation into mixed fields.

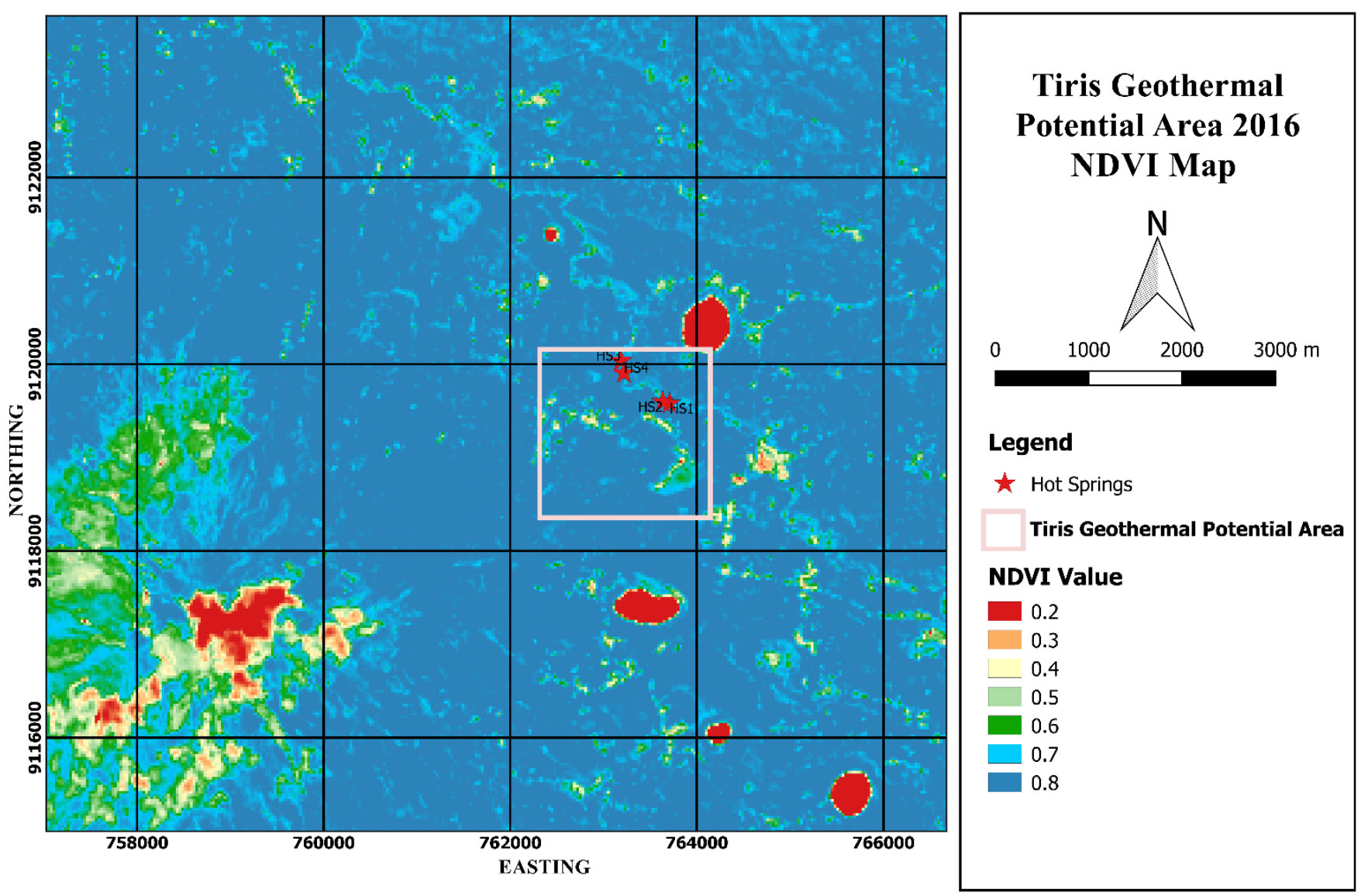

Figure 2: Tiris Geothermal Potential Area 2016 NDVI Map. 


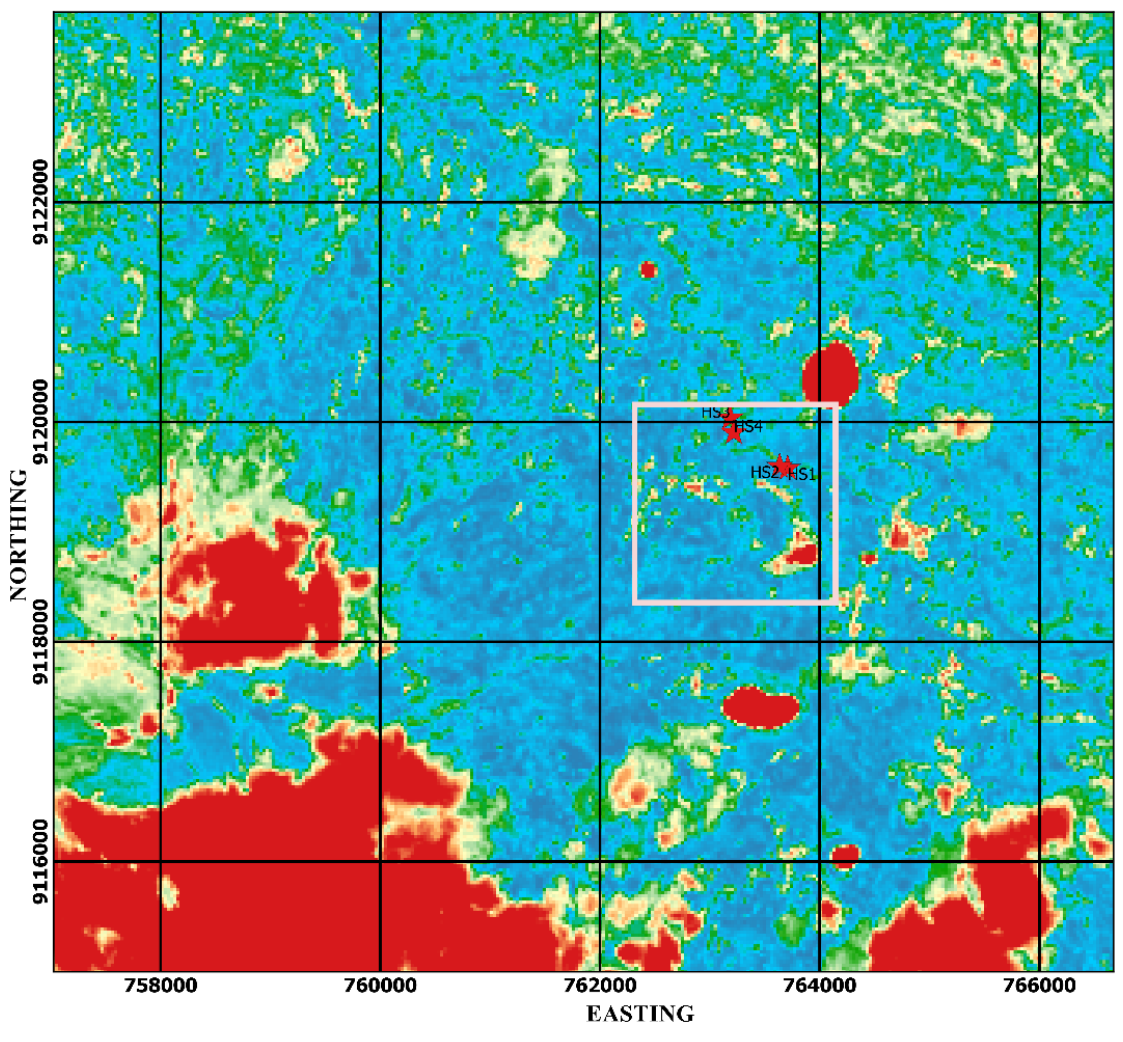

Tiris Geothermal Potential Area 2017 NDVI Map.
Tiris Geothermal

Potential Area 2017

NDVI Map

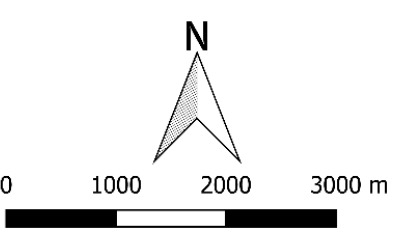

Legend

$\star$ Hot Springs

Tiris Geothermal Potential Area

\section{NDVI Value}

\section{2}

0.3

$-0.4$

0.5

0.6

0.7

0.8

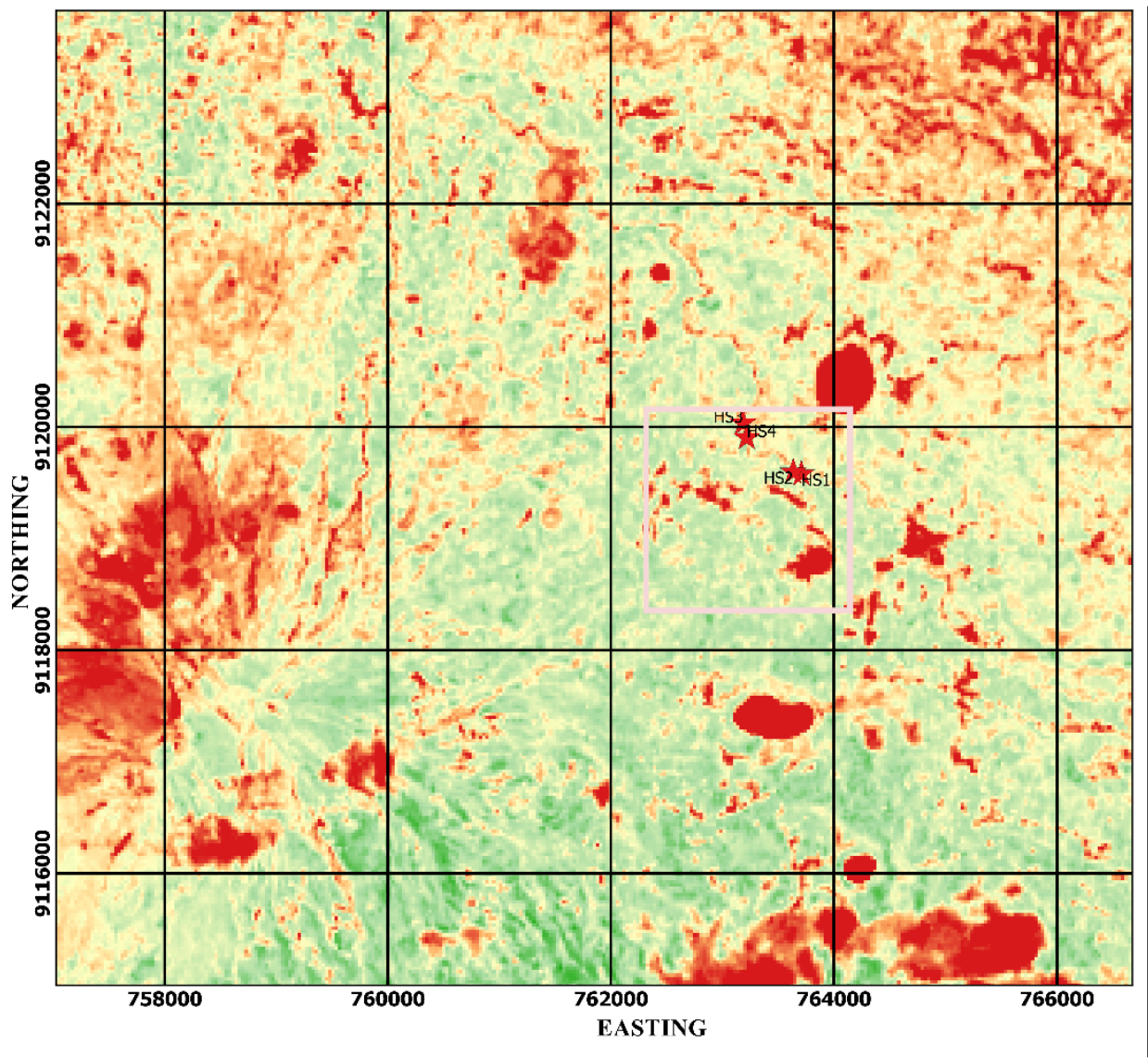

Figure 3:

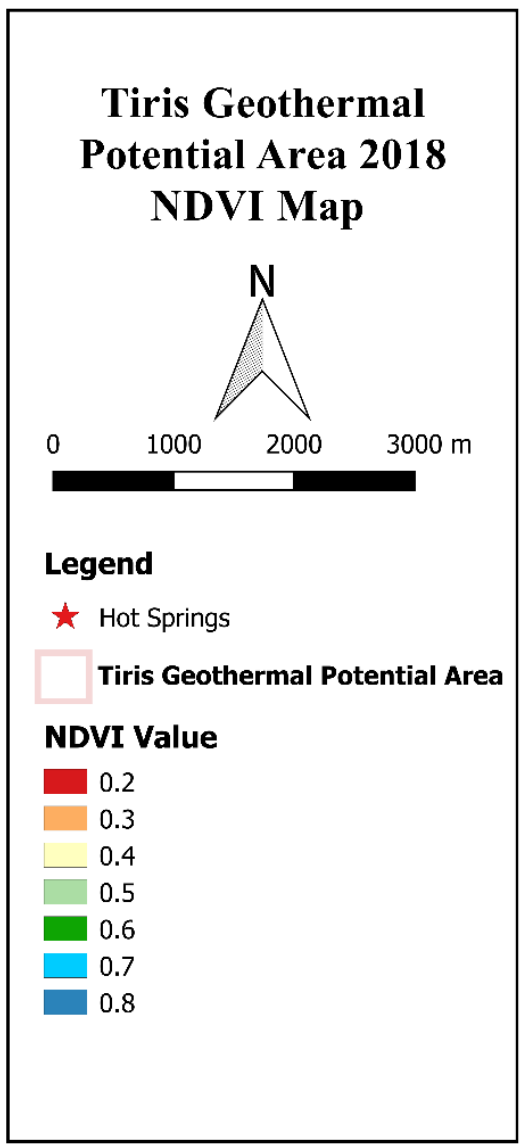

Figure 4: Tiris Geothermal Potential Area 2018 NDVI Map. 
Figure 5 shows variate distribution of temperature in year 2016 is between $20^{\circ} \mathrm{C}-26^{\circ} \mathrm{C}$ and in Tiris area have some spot that have temperature higher compared to the surroundings. Figure 6 shows an increase in temperature distribution, especially in the North and Northwest with range ranging from $20^{\circ} \mathrm{C}$ to $30^{\circ} \mathrm{C}$ and in Tiris area still showing the same pattern. Figure 7 also shows an increase in temperature distribution in almost all areas.
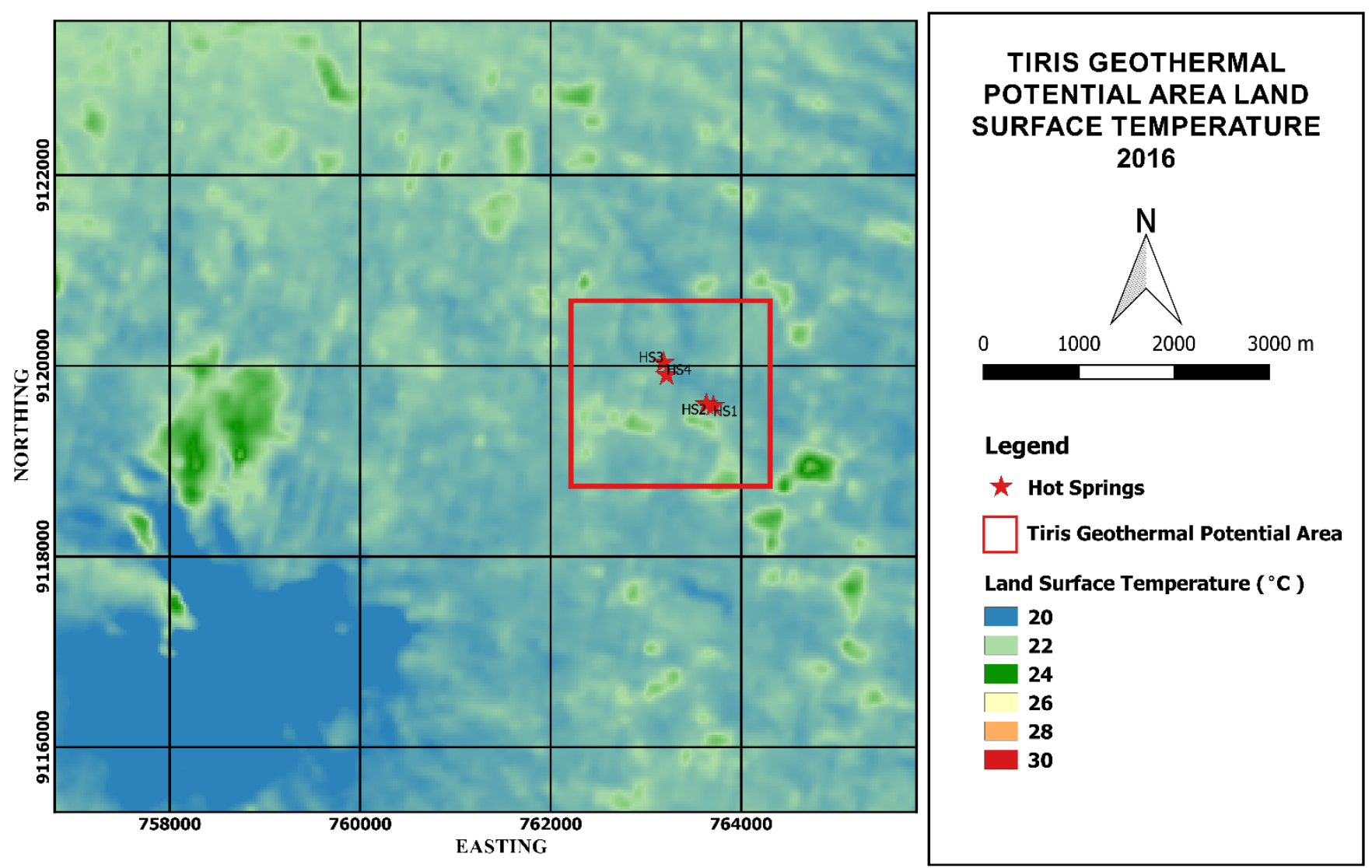

Figure 5: Tiris Geothermal Potential Area Land Surface Temperature Year 2016.
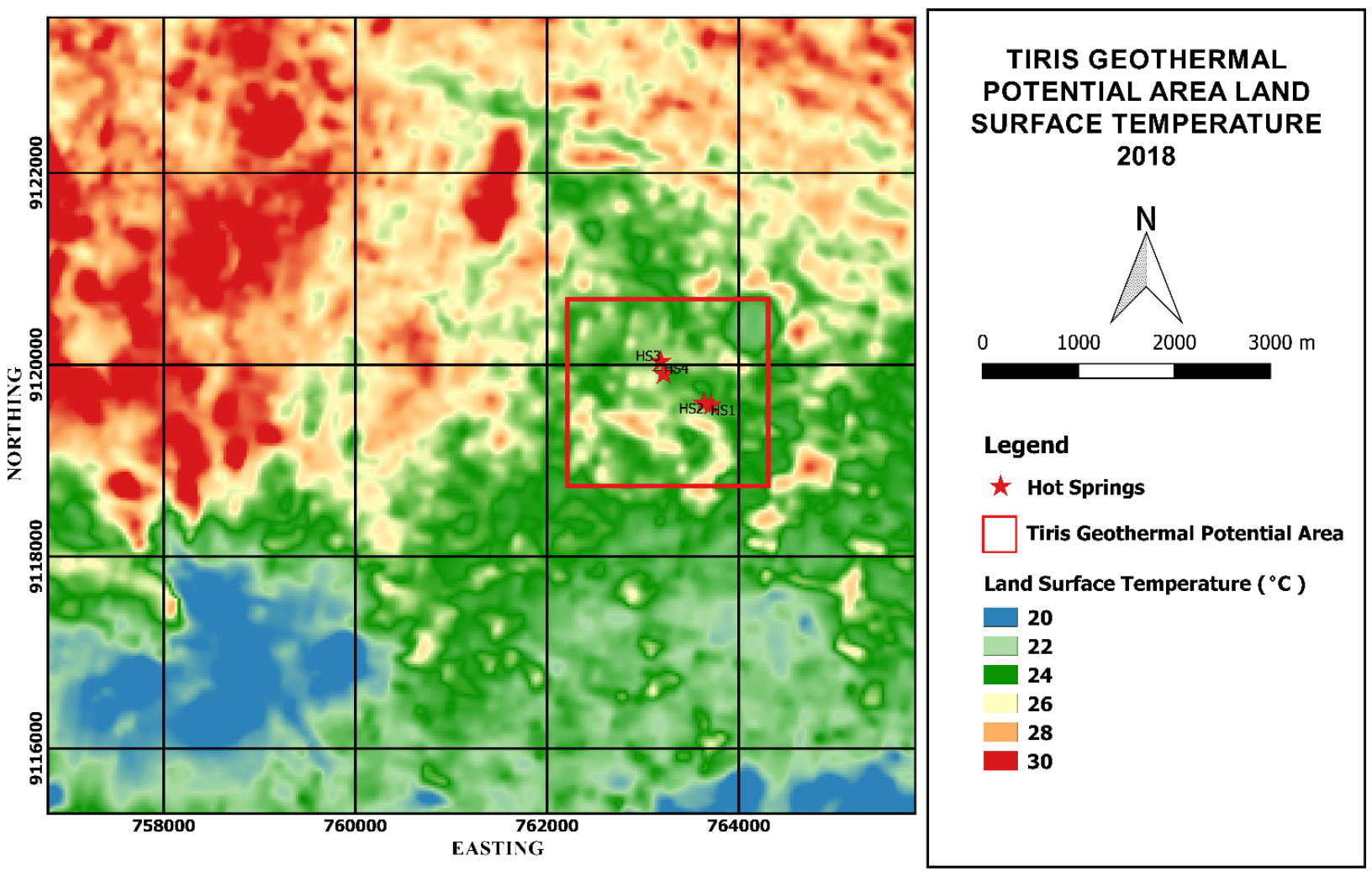

Figure 6: Tiris Geothermal Potential Area Land Surface Temperature Year 2017. 


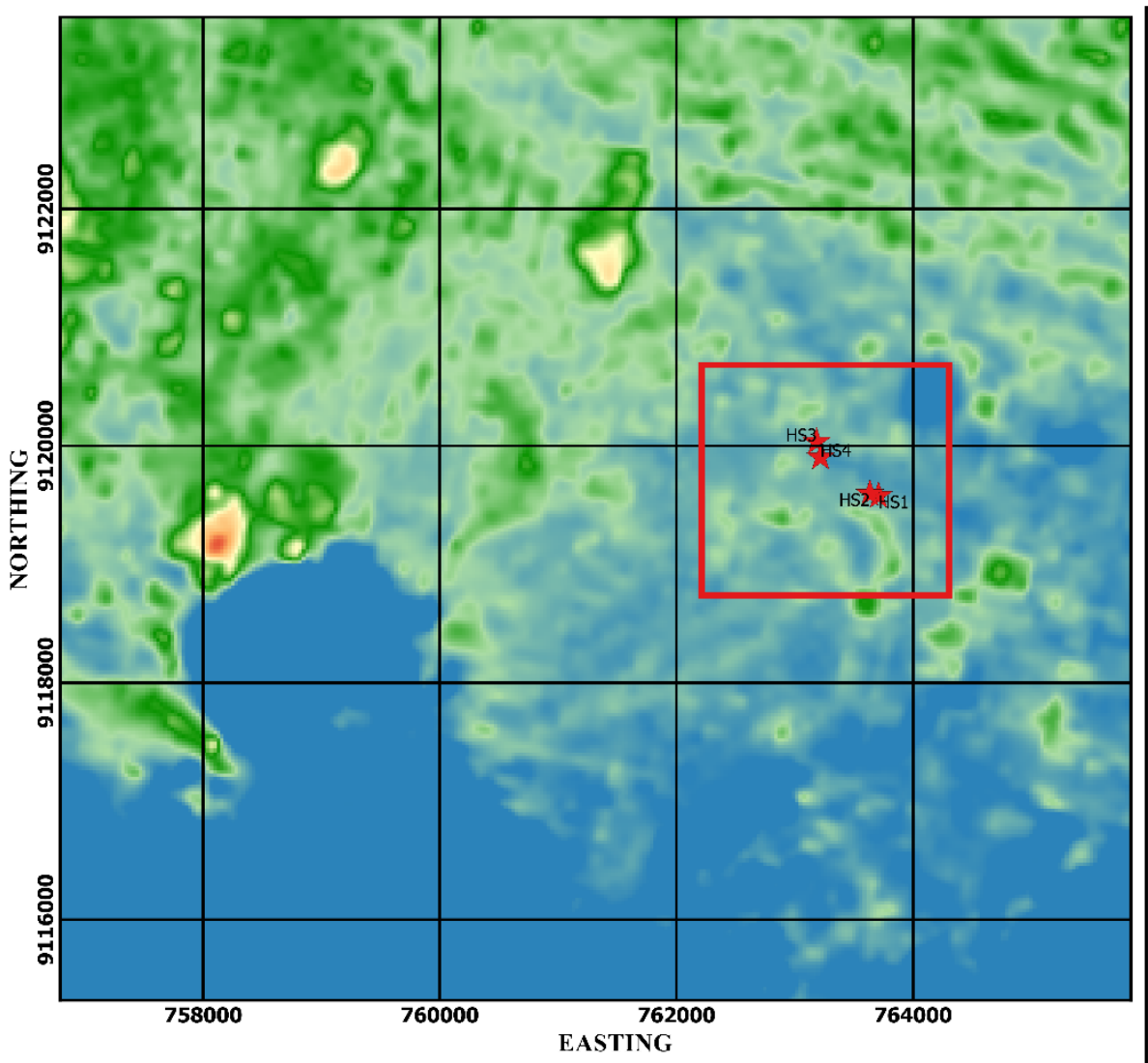

TIRIS GEOTHERMAL

POTENTIAL AREA LAND SURFACE TEMPERATURE

2017

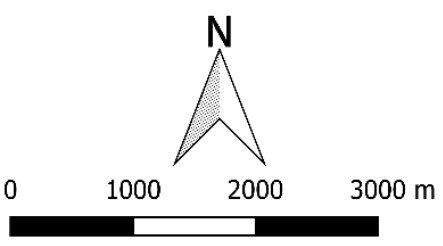

Legend

$\star$ Hot Springs

$\square$ Tiris Geothermal Potential Area

Land Surface Temperature $\left({ }^{\circ} \mathrm{C}\right)$

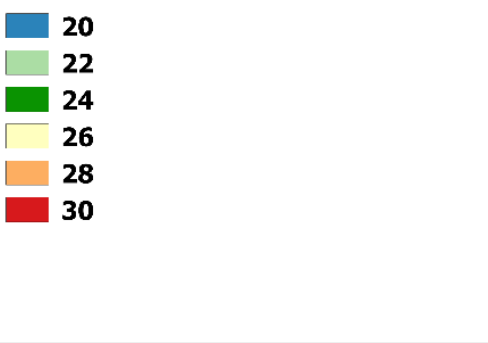

Figure 7: Tiris Geothermal Potential Area Land Surface Temperature Year 2018.

From the three images (Figure 5 - 7), it can be seen that each year the Tiris geothermal potential area increases in temperature, and hot spot in that area has a much higher temperature than the surrounding area. Distribution of land surface temperature when overlaid with Tiris regional geology map, can be seen in figure 8 - 10. As seen that the location of the hot springs is right next to the Tiris fault and hot spot inside the area is also near to the fault. As it is known that hot springs can arise due to water seeping out of the reservoir due to a fault, so it can be assumed that the hot spots in the Tiris geothermal area are geothermal reservoir. 

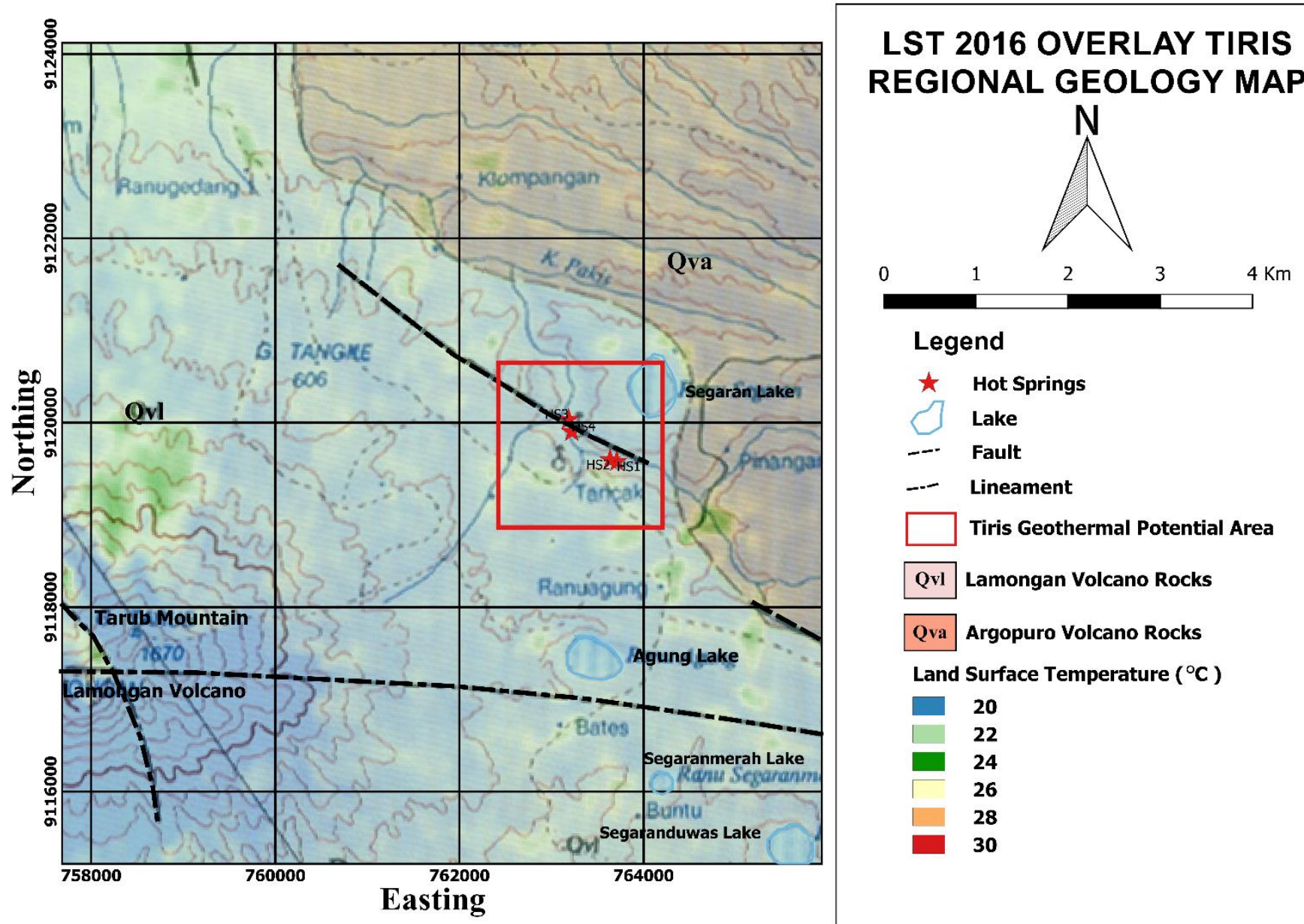

Figure 8: Overlay of LST Year 2016 with Tiris Geology Map modified from Suharsono and Surwati, 1992.
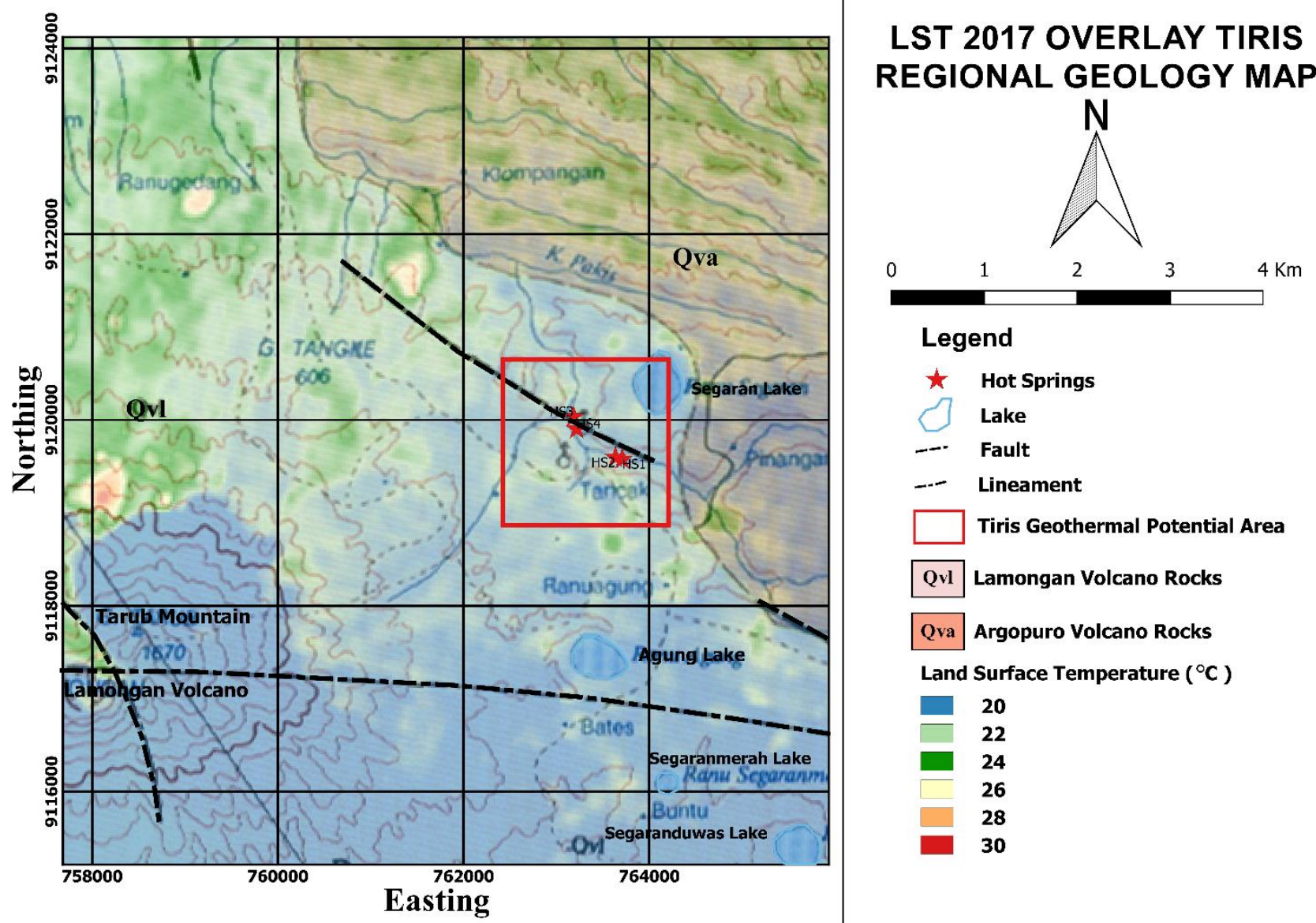

\section{Legend}

$\star \quad$ Hot Springs

Lake

-. Fault

-.- Lineament

$\square$ Tiris Geothermal Potential Area

Qvi Lamongan Volcano Rocks

Qva Argopuro Volcano Rocks

Land Surface Temperature $\left({ }^{\circ} \mathrm{C}\right)$

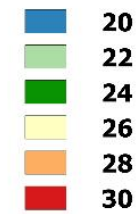

Figure 9: Overlay of LST Year 2017 with Tiris Geology Map modified from Suharsono and Surwati, 1992. 


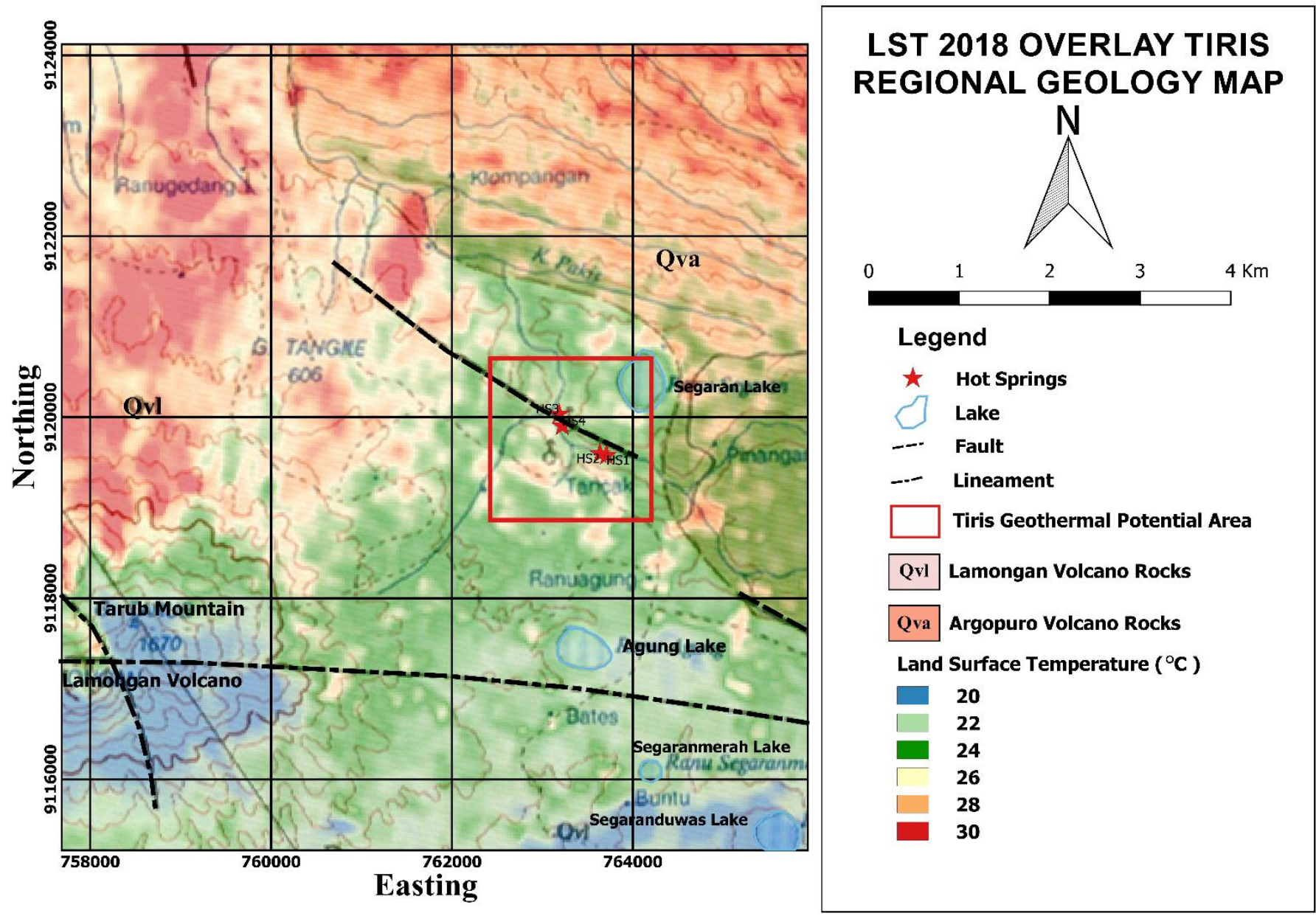

Figure 10: Overlay of LST Year 2018 with Tiris Geology Map modified from Suharsono and Surwati, 1992.

4. CONCLUSION

From the result of the data process, it is known that in the Tiris Geothermal Potential Area every year from 2016 to 2018 there is a decrease in distribution of NDVI value but increase in distribution of land surface temperature. Also found hot spots in the area that have higher temperatures than the surroundings. With the overlaid of the Tiris Regional Geology Map, it can be seen that the location of the hot spot is near from Tiris fault, so this hot spot area is possible to be Tiris geothermal reservoir and can be a focus area for further research using other geophysical method.

\section{ACKNOWLEDGEMENT}

We acknowledge chairman and member of Brawijaya Volcano and Geothermal Research Center (Bravo GRC), Brawijaya University for moral and partially financial support for this research.

\section{REFERENCES}

[1] Directorate of Geothermal Energy, Directorate General of EBTKE, Resources Center of Mineral, Coal, Geothermal, and Geology Agency . 2017. Indonesia's Geothermal Potential, Jakarta: Minister of Energy and Mineral Resources, 1, 747-754.

[2] Maryanto, S., Wicaksono, A., Azhari, A., Dewi. C. 2015. Multi Geophysical Observations at Blawan - Ijen Volcano Geothermal Complex for Regional Development. Journal of Enviromental Engineering Sustainability Technology, 2(2), 105-113.

[3] Ermanto, S. A., Maryanto, S., Susilo, A. 2017. Determination of Wurung Crater Surface Temperature - Ijen East Java Using Landsat Image 8 as A Preliminary Study In the Geothermal Exploration Survey. Natural-Biology, 4(1), 50-56.

[4] Juniarti, E., Maryanto, S., Susilo. A. 2017. Mapping the surface temperature of wurung creater area, Bondowoso Regency, East Java in Determining Geothermal Manifestations. Natural-Biology, 4(1), 65-72.

[5] Raehanayati, Rachmansyah, A., Maryanto., S. 2013. Study of Geothermal Energy Potential of Blawan-Ijen, East Java Based on Graviti Method. Journal Neutrino, 6(1), 31-39.

[6] Maryanto, S., Suciningtyas, I. K. L. N., Dewi, C. N., Rachmansyah., A. 2016. Integrated Resistivity and Ground Penetrating Radar Observations of Underground Seepage of Hot Water at Blawan-Ijen Geothermal Field. International Journal of Geophysics.

[7] Maryanto, S. 2017. Geo Techno Park potential at Arjuno-Welirang Volcano hosted geothermal area, Batu, East Java, Indonesia (Multi geophysical approach). AIP Conference Proceedings, 1908, 030012.

[8] Maryanto, S. et al. 2017. Magnetotelluric-Geochemistry Investigations of Blawan Geothermal Field, East Java, Indonesia. Geosciences, 7(2), 41.

[9] Maryanto., S. 2018. Preliminary Investigation of Volcano Hosted Geothermal Area at Kasinan-Songgoriti-Cangar, Batu city, Based on Gravity-Seismic Methods. AIP Conference Proceedings, 2021.

[10] Maryanto, S., Siombone, S. H., Prayogo, A., Yulia, T., Sari. R. P. H. 2018. Preliminary Study: Density Layer Values Estimation of Volcano Hosted Geothermal Area at Tiris Village , Probolinggo Regency , East Java , Indonesia. International Journal of Applied Engineering Research, 13(6), 4385-4390.

[11] Suharsono, Surwati, T. 1992. Geological Map of The Probolinggo Quadrangle, Jawa. Geological Research and Development Centre, Bandung.

[12] Faridah, S. A. N., Krisbiantoro, A. 2014. Land Surface Temperature Distribution Analysis in Potential Area of Geothermal Using Remote Sensing Techniques on Mount Lamongan, Tiris. Berkala Fisika, 17(2), 67-72.

[13] Darge, Y. M., Hailu, B. T., Muluneh, A. A., Kidane, T. 2019. Detection of Geothermal Anomalies Using Landsat 8 TIRS Data in Tulu Moye Geothermal Prospect, Main Ethiopian Rift. International Journal Applied Earth Observation and Geoinformation, 74, 16-26.

[14] Wright, J., Lillesand, T. M., Kiefer, R. W. 1980. Remote Sensing and Image Interpretation. Geographic Journal, $146(3), 448$.

[15] USGS. 2018. Landsat 8 Surface Reflectance Code (LASRC) Product Guide, Version 1. Sioux Falls, South Dakota: Department of Interior U.S. Geological Survey.

[16] USGS. 2018. Landsat 4-7 Surface Reflectance (LEDAPS) Product Guide, Version 1. Sioux Falls, South Dakota: Department of Interior U.S. Geological Survey. 
[17] USGS. 2018. Landsat Surface Temperature (ST) Product Guide, Version 2. Sioux Falls, South Dakota: Department of Interior U.S. Geological Survey.

[18] USGS. 2016. Landsat 8 (L8) Data Users Handbook, Version 2. Sioux Falls, South Dakota: Department of Interior U.S. Geological Survey.

[19] Qin, Q, Zhang, N., Nan P., Chai, L. 2011. Geothermal Area Detection Using Landsat ETM+ Thermal Infrared Data and Its Mechanistic Analysis-A Case Study in Tengchong, China. International Journal Applied Earth Observation and Geoinformation, 13(4), 552-559.

[20] Sobrino, J. A., Jiménez-Muñoz, J. C., Paolini, L. 2004. Land Surface Temperature Retrieval From LANDSAT TM 5. Remote Sensing of Environment, 90(4),

434-440. 